\title{
MECHANISM OF FINANCIAL SAFETY FORMATION OF ENTERPRISES OF AGROINDUSTRIAL COMPLEX
}

\author{
Aleksandr KHOMENKO' \\ Podillia State Agricultural and Technical University, Ukraine
}

\begin{abstract}
The purpose of work is research of essence of mechanism of forming of financial safety of subjects of agro-industrial complex as to the economic category. Basic financial interests of business entity and financial tasks are certain for their achievement. Considered organization of forming of financial safety of enterprises of agroindustrial complex and offered the measures of realization of the effective system of defence of subjects. The system of financial safety is directed foremost on providing of the own functioning, however, it is necessary to underline that at the same time it is a component part, both at the level of structural subdivisions of subject and at the level of industry, region, state. Financial safety of agrarian sphere is the important constituent of economic security of the state, which acquires an important value for further development of country. Methodology. Methodological basis of the article are methods of scientific cognition, which enable to expose basic conformities to law of development of the probed phenomena and processes, their key problems and priority ways of decision. Such methods are in particular used: analysis and synthesis - during research of constituents of economic security of agricultural enterprises, in particular such as financial safety, and to their aggregate on the whole; systematizations - for dismemberment and more rich in content understanding of essence of the separate probed phenomena and processes; to scientific abstraction - with the purpose of forming of theoretical generalizations and conclusions. A research result is opening of mechanism of financial safety forming of agro-industrial enterprises on the modern stage of socio-economic development of Ukraine. The offered model of strategic prognostication has for an object development of strategy of forming of financial safety of enterprises of agro-industrial complex. Such strategy must avouch for financial prospects enterprises, to answer their aims. As a result, depending on the worked out strategy of financial safety, it is possible to draw basic directions of guaranteeing his financial safety activity of enterprises of agro-industrial complex. Organizational-economic principles of forming of mechanism of financial safety of agricultural enterprises must be built on the basis of realization of its expressly certain strategy. It, in same queue, must go out from present of their production potential. This strategy is the basic internal reference-point of forming of financial safety of agricultural enterprise that sets the parameters of all her development. Practical implications. On financial safety of enterprises of agro-industrial complex testifies the conducted analysis of scientific researches, that without regard to the wide list of existing in economic literature researches on the mechanism of forming of enterprises' financial safety, among scientific circles until now there is not a general idea. It requires forming of new knowledge's in relation to forming of mechanism of enterprise financial safety, where not only the certain state of subject but also dynamic constituent of development must come forward as a priority lever, what is considered in this article. Value/originality. Creation of valuable mechanism of forming of financial safety of agro-industrial enterprises foresees formulation of criteria and principles of providing of financial safety of every enterprise, determinations of priority national interests in a financial sphere, realization of the permanent watching of factors, which cause a threat financial safety, and also acceptance of measures in relation to their warning and overcoming. The formed mechanism of financial safety of the agricultural formations is pre-condition of prevention of financial threats and negative financial phenomena in production activity of the agricultural formations, defence of their financial losses, and in future stabilizing of activity of the agricultural formations and development in the conditions of competition economic position.
\end{abstract}

Key words: financial safety, economic security, management, mechanism of forming of financial safety, threats, risks.

JEL Classification: G29, A23, Q14, G32, L29

Corresponding author:

${ }^{1}$ Department of Management of Organizations and Administration, Podillia State Agricultural and Technical University.

E-mail: kentos@ua.fm 


\section{Introduction}

Substantial influence on efficiency of financial mechanism of financial safety of business entity is caused by rapid changeableness of economic environment that is observed lately. The changes of cooperation's between business entities, between business entities and state, between business entities and credit establishments or other economic agents determine the redistribution of financial streams, which in turn, stipulates the changes of structure of the economic system of society, and thus, recombination of dangers and threats. In every separate moment every economic agent is subject to influence of individual totality of dangers and threats that change constantly.

Providing of financial safety of enterprises of agroindustrial complex must be based on the integrated approach, that allows to coordinate and coordinate actions, that is sent to providing of protecting from threats as external and internal environment of enterprises and to provide possibility to warn the threats of financial safety of enterprises with next development of certain recommendations and suggestions sent to the increase of financial strength of enterprises of agro-industrial complex security.

Financial safety is a universal category that characterizes security of subjects of socio-economic relations on all levels, beginning from the state and ending every its citizen (Baranovskiy, 1996).

The problem of forming of financial safety of enterprises of agro-industrial complex engaged in Baranovskiy I.O., Blank I.O., Vitlinskiy V.V., Pidkhomniy O.M., Ermoshenko M.M., Kravchuk N.Y., Mishina I.G. et al (Baranovskiy, 1996, Blank, 2004, Vitlinskiy, 2000, Pidkhomniy, 2007, Ermoshenko, 1998, Kravchuk, 2000, Mishina, 2003).

However, comprehending their payment in the decision of different theoretical and practical tasks to the mechanism of forming of financial safety of enterprises of agro-industrial complex, it should be noted a shortage of the complex, integrated going is near their lineation.

List of tasks, and today, remain debatable and intelligent not enough and worked out, that does not give an opportunity effectively to construct the mechanism of financial safety of enterprises of agro-industrial complex. In particular, rich in content presentation failing in relation to constructing of the stages of mechanism of forming of financial safety of enterprises of agro-industrial complex, that was hidden, as the forgotten area of the integrated diagnostics of processes and phenomena of menage, requirements are not identified to constructing of potential of financial safety of enterprises of agroindustrial complex on the market scenario of menage, not untied methodological tasks of forming of financial safety, methodical approaches are worked not enough out in relation to the quantitative measuring of composition and parameters of mechanism of financial safety and still a discussion lasts in relation to the lineation of maintenance of forming of financial safety of enterprises of agro- industrial complex, events and directions of guaranteeing of them financial safety.

Constructing of mechanism of financial safety of agro-industrial enterprises is a process of authentication and forming of spectrum of economic feasibilities, its composition and construction of certain organizational forms for permanent financial advancement and effective recreation. Will outline more careful stages of forming of financial safety of agro-industrial enterprises having regard to that it is an elaborate economic design with inherent only by certain signs and properties.

\section{Stages of forming of financial safety}

For development of mechanism of financial safety it is necessary to untie such tasks as authentication of dangers and threats of enterprises of agro-industrial complex; lineation of indicators of financial safety; development of monitoring indexes is after financial constancy and safety; development of the events orientated on guaranteeing of enterprises financial safety; control is after implementation of events; diagnostics of implementation of events, their change; changes of indicators and indexes are depending on oscillation to the contour of external space, aims and tasks of enterprises of agroindustrial complex (Chibisova, \& Ivashina, 2011).

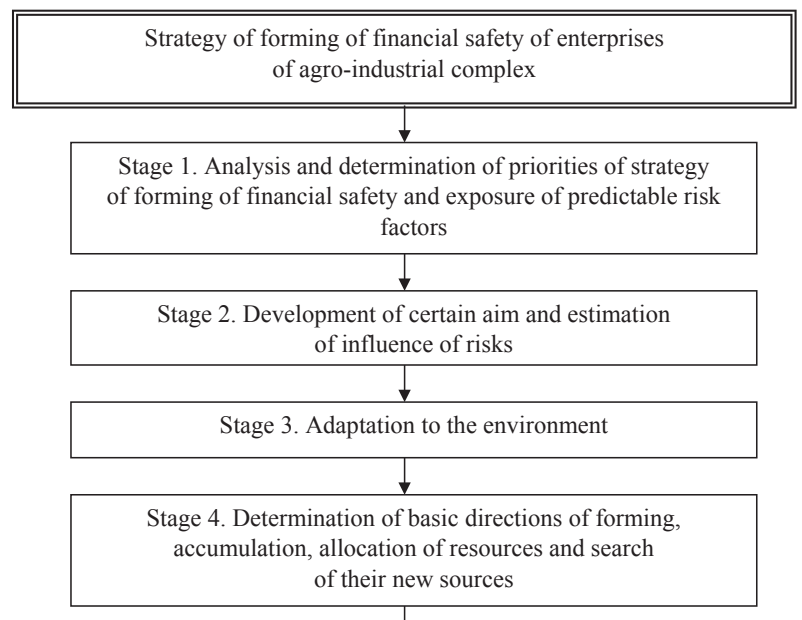

Stage 5. Development of strategy elements of forming of financial safety of enterprises of agro-industrial complex and choice of method of risks minimization

\section{1}

Stage 6. Development of strategy of forming of financial safety and minimization of financial risks

$$
\checkmark
$$

Stage 7. Realization of strategy of financial safety forming and application of methods of risks minimization

Stage 8. Analysis and control of strategy of forming of financial safety and estimation of results of minimization of risks

Stage 9. Drawing on the analysis results, the specification of strategic directions of development of agro-industrial enterprises

Pic. 1. Stages of strategy of forming of financial safety of enterprises of agro-industrial complex. 
Leaning on the tasks, it is possible to work out the mechanism of strategy of financial safety of enterprises of agro-industrial complex that must include:

- it is a lineation of totality of criteria, indexes and parameters (quantitative and quality contours) of potential of financial safety of enterprises of agro-industrial complex;

- development of events totality of threats authentication of financial safety of agro-industrial enterprises and their transmitters;

- description of contours of their display and localization; - it is a disclosing of basic subjects of threats, charts of their functioning, contours of their influence on financial safety of enterprises of agro-industrial complex;

- development of methodology of prognostication, disclosure of factors, that outline the threats of financial safety, disclosure of trends and possibilities of advancement of such threats;

- constructing of mechanisms and events that neutralize or soften influence of unfavourable factors;

- lineation of objects, objects, parameters of control of financial safety of enterprises of agro-industrial complex.

The result of the strategic planning must be the worked out strategy of constructing of financial safety of enterprises of agro-industrial complex (Prikazyuk, 2009). Such strategy must avouch for financial prospects an enterprise, to answer their task (Picture 1).

At development of strategy of financial safety of enterprises of agro-industrial complex, foremost follows to outline such its basic segments as diagnostics, strategic planning and prognostication, control, audit (Martyusheva, 2006).

\section{Strategic aims of financial safety}

The strategic whole providing of financial safety of enterprise present those desirable parameters her eventual strategic position, that allow to direct the system of events of defence of financial interests from threats in a long-term prospect and to estimate their results.

The mechanism of financial safety of enterprise allows: to provide financial firmness, liquidity, solvency; independently to develop and inculcate financial strategy; providing the optimal bringing in and effective use of financial resources of enterprise and providing sufficient financial independence of enterprise.

Expediency of realization of totality of the marked events depends on the worked out financial strategy of enterprise, it is possible to draw basic directions of guaranteeing of him financial safety (Kuzenko, Martyusheva, Grachov, \& Litovchenko, 2010).

Principles of financial safety, such as an equivalence, forecast, equality of rights and stability, are important constituent of mechanism of providing of financial safety on an enterprise, without them it is impossible to consider all structure of mechanism and trace its meaningfulness for providing of financial safety on an enterprise.

It follows to admit basic directions of strengthening of financial safety of enterprises of agro-industrial complex : constructing of necessary pre-conditions for a construction, advancement and functioning of permanent mechanism of financial safety;

- working of strategy of financial safety, prognostication and drawing of certain measures in relation to her effectiveness; - foresight, authentication and measuring of latent possible indignations, totality of destabilizing factors and their sources;

- lineation of parameters safe to the contour of enterprises of agro-industrial complex and lineation of indicators of financial safety.

The system of defence of financial secret of enterprises of agro-industrial complex must include such successive events:

- disguise of list of information that is considered a financial secret;

- determination of time of existence of varieties of confidential information;

- claim of list of information and determination of transmitters of information that is confessed by the financial secret of enterprise;

- selection of methods and charts of defence of financial secret;

- control after the observance of totality of safety measures.

Application of the indicated stages in-process enterprises of agro-industrial complex will give an opportunity to decrease crisis processes in enterprises and increase financial strength security due to the increase of their level of development in the conditions of market vibrations.

However, the increase of financial strength of enterprises of agro-industrial complex security is done by impossible in default of sponsorship from the side of the state, in particular, the obligatory is confess the grant of state subsidies, especially, purchase by the state after the certain standard of prices of agrarian products and decline of tax pressure (Sabluk, 2008).

Certain determinants of forming of financial safety of enterprises of agro-industrial complex give possibility to take into account the specific of every enterprise and general transformations of financial space of Ukraine and must create terms for the financial increase of production, high competitiveness of products, to support scientific and technical potential, shut out the decline of level to the contours of critical zones, to save financial stability of enterprises of agrarian sphere.

\section{Conclusions}

Forming of financial safety of enterprises of agroindustrial complex is the process of authentication and creation of spectrum of financial possibilities, that are in permanent dynamic transformation under act of external and internal terms, its composition and construction of certain organizational forms for stable financial advancement and effective recreation with an orientation on a teaming-up them financial assets and providing of necessary proportions of functioning through 
intercommunication of its subjective and objective component segments.

Providing of financial safety of enterprises of agroindustrial complex must be the constituent of enterprise strategic management that allows to perfect going near its determination as to the system of economic relations, arising up between the organs of management and different groups of agents, concerning realization of long-term interests and aims of enterprise, including by providing of financial safety.

As a result, depending on select strategy of financial management it is possible to draw basic directions of guaranteeing of financial safety of enterprises of agroindustrial complex and their activity.

\section{References}

Baranovskiy, O.I. (1996). Financial safety of the state. Finances of Ukraine, 11, 19-34.

Blank, I.A. (2004). Management financial safety of enterprise. Kiev: Nika-center.

Chibisova, I. V., \& Ivashina, E. M. (2011). Mechanism of providing of financial safety of enterprise. Retrieved from: http://www.nbuv.gov.ua/portal/soc_gum/ppei/2011_31/chibis.pdf.

Ermoshenko, M. M. (1998). Basic principles of increase of financial safety of the state. The Strategic panorama, 1-2, 99-114.

Kravchuk, N. Y. (2000). Financial safety of the state : reality and expediency in the conditions of globalization. Announcer of Ternopil Academy of national economy. Ternopil, 9, 121-126.

Kuzenko, T. B., Martyusheva, L. S., Grachov, O. V., \& Litovchenko O. Y. (2010). Financial safety of enterprise. Kharkiv: the Kharkiv national economic university.

Martyusheva, L. S. (2006). Financial safety of enterprise as independent object of management. Communal economy of cities, 71, 235-238.

Mishina, I. G. (2003). Financial risks: prognostication of degree of their influence on economic security of enterprise. Problems and prospects of steady development of tourism and service business in the world and in Ukraine. Doneck, 111-114.

Pidkhomniy, O. M. (2007). Typology of threats to financial safety of performers of entrepreneurial activities. Management and enterprise in Ukraine: stages of becoming and problem of development. Lviv: «Lviv politekhnika $\gg, 119-123$.

Prikazyuk, O. V, (2009). Profit in forming of financial safety of agricultural enterprises. Banking, 2, 82-88.

Sabluk, P. T. (2008). State and prospects of development of agroindustrial complex of Ukraine. Economy of Ukraine, 12, 4-18.

Vitlinskiy, V. V. (2000). Sistemne the use of objective and subjective indexes of risk in a financially economic sphere. Finances of Ukraine, 12, 16-24.

\section{Александр ХОМЕНКО}

\section{МЕХАНИЗМ ФОРМИРОВАНИЯ ФИНАНСОВОЙ БЕЗОПАСНОСТИ ПРЕДПРИЯТИЙ АГРОПРОМЫШЛЕННОГО КОМПЛЕКСА}

Аннотация. Целью работы является исследование сущности механизма формирования финансовой безопасности субъектов агропромышленного комплекса как экономической категории. Определены основные финансовые интересы субъекта предпринимательства и финансовые задачи для их достижения. Рассмотрены организация формирования финансовой безопасности предприятий агропромышленного комплекса и предложены меры реализации действенной системы защиты субъектов. Система финансовой безопасности направлена прежде всего на обеспечение собственного функционирования, однако, следует подчеркнуть, что в то же время она является и составной частью, как на уровне структурных подразделений субъекта, так и на уровне отрасли, региона, государства. Финансовая безопасность аграрной сферы является важной составляющей экономической безопасности государства, которая приобретает важное значение для дальнейшего развития страны. Методика. Методологической основой при написании статьи являются методы научного познания, которые дают возможность выявить основные закономерности развития исследуемых явлений и процессов, их ключевые проблемы и приоритетные пути решения. В частности использованы такие методы: анализ и синтез - во время исследования составляющих экономической безопасности сельскохозяйственных предприятий, в частности таких как финансовая безопасность, и их совокупности в целом; систематизации - для расчленения и более содержательного понимания сути отдельных исследуемых явлений и процессов; научной абстракции - с целью формирования теоретических обобщений и выводов. Результатом исследования является раскрытие механизма формирования финансовой безопасности предприятий агропромышленного комплекса на современном этапе социальноэкономического развития Украины. Предложенная модель стратегического прогнозирования имеет целью 
разрабатывание стратегии формирования финансовой безопасности предприятий агропромышленного комплекса. Такая стратегия должна гарантировать финансовые перспективы предприятиям, отвечать их целям. Как следствие, в зависимости от проработанной стратегии финансовой безопасности, можно начертить основные направления гарантирования его финансовой безопасности деятельность самих предприятий агропромышленного комплекса. Организационно-экономические принципы формирования механизма финансовой безопасности сельскохозяйственных предприятий должны строиться на основе реализации четко определенной ее стратегии. Она, в свою очередь, должна выходить из имеющегося их производственного потенциала. Эта стратегия является основным внутренним ориентиром формирования финансовой безопасности сельскохозяйственного предприятия, которое задает параметры всего ее развития. Практические значения. Проведенным анализом научных исследований по финансовой безопасности предприятий агропромышленного комплекса свидетельствует, что невзирая на широкий перечень существующих в экономической литературе исследований по механизму формирования финансовой безопасности предприятий, среди научных кругов до сих пор нет общей мысли. Это требует формирования новых знаний относительно формирования механизма финансовой безопасности предприятия, где в качестве приоритетного рычага должно выступать не только определенное состояние субъекта, но и динамическая составляющая развития, что и рассмотрено в данной статье. Значение/оригинальность. Создание полноценного механизма формирования финансовой безопасности предприятий агропромышленного комплекса предусматривает формулировку критериев и принципов обеспечения финансовой безопасности каждого предприятия, определения приоритетных национальных интересов в финансовой сфере, осуществление постоянного отслеживания факторов, которые вызывают угрозу финансовой безопасности, а также принятие мер относительно их предупреждения и преодоления. Сформированный механизм финансовой безопасности сельскохозяйственных формирований является предпосылкой предотвращения финансовых угроз и негативных финансовых явлений в производственной деятельности сельскохозяйственных формирований, защиты их финансовых потерь, а в дальнейшем стабилизации деятельности сельскохозяйственных формирований и развития в условиях конкурентного экономического положения. 